\title{
Morphometric Analysis and Prioritization of Sub Watersheds of Umar Nala Watershed, Madhya Pradesh Using Geospatial Technique
}

\author{
Snehil Dubey ${ }^{1 *}$, J. Himanshu Rao ${ }^{2}$ and Deepak Patle ${ }^{2}$ \\ ${ }^{1}$ Departemnt of Farm Engineering, Institute of Agricultural Sciences, Banaras Hindu University, Varanasi, Uttar Pradesh, India \\ ${ }^{2}$ Department of Soil \& Water Engineering, College of Agricultural Engineering, J.N.K.V.V., Jabalpur, Madhya Pradesh, India
}

*Corresponding author: snehildubey002@gmail.com (ORCID ID: 0000-0001-9552-3733)

Paper No. 847

Received: 14-04-2020

Revised: $17-07-2020$

Accepted: 28-08-2020

\begin{abstract}
Morphometric analysis and thereby prioritization of watersheds have gained significant importance in land and water resources management. In this study an attempt has been made to prioritize subwatersheds based on morphometric analysis using geospatial techniques in Umar Nala watershed of Narsinghpur district, of Madhya Pradesh. Morphometric parameters, considered for the present study are stream frequency $\left(S_{f}\right)$, drainage density $\left(D_{d}\right)$, texture ratio $(T)$, elongation ratio $\left(R_{e}\right)$, circulatory ratio $\left(R_{c}\right)$, form factor $\left(R_{f}\right)$, bifurcation ratio $\left(R_{b}\right)$ and relief ratio $\left(R_{h}\right)$. These parameters were estimated for each subwatershed then ranks were assigned for prioritization of sub-watersheds on the basis of value/relationship to arrive at a computed value for final ranking of the sub-watersheds. On the basis of morphometric parameters determined in GIS environment and then applying standard formulae prioritization among seventeen sub watersheds of Umar Nala, sub watershed no 10 is on top priority among seventeen sub watersheds for further soil and water conservations measures to be taken in the watershed.

\section{Highlights}

( This study conducted in Umar Nala watershed of Narsinghpur, district of Madhya Pradesh, India to prioritize sub-watersheds based on morphometric analysis using geospatial techniques.

(0 In this study, we employed seventeen sub watersheds of Umar Nala, and found which watershed urgently requires soil and water conservation measures.
\end{abstract}

Keywords: GIS, Morphometric Analysis, Prioritization, Watershed.

Population of our country is increasing over the years as a result pressure on natural resources also increasing (Sharma et al. 2016). So, it necessitates management and development of land and water resources on watershed basis (Sharma et al. 2008; Sharma et al. 2010). Watershed is a hydrological unit from which precipitation water flows to a common outlet or single point into small and large streams, rivers or oceans (Sharma et al. 2011; Patil et al. 2016, Rao, 2019; Rao et al. 2019). Geospatial technique has emerged as powerful tool to manage watersheds (Sharma et al. 2013; Patle and Awasthi, 2019a: Patle and Awasthi 2019b).

Quantitative description of any watershed is an aspect which is important to characterize any watershed, which can be made easily by morphometric analysis of the watershed (Strahler 1964). Linear, aerial and relief aspects of watershed require measurement of watershed area, its perimeter, stream number, stream length to make morphometric analysis (Sharma and Seth 2010). Strahler (1964), Miller (1953), Smith (1950), Horton $(1932,1945)$, and others carried out pioneering work on the drainage basin morphometry.

How to cite this article: Dubey, S., Rao, J.H. and Patle, D. (2020). Morphometric Analysis and Prioritization of Sub Watersheds of Umar Nala Watershed, Madhya Pradesh Using Geospatial Technique. IJAEB, 13(3): 269-274.

Source of Support: None; Conflict of Interest: None 
Prioritization of sub-watersheds based on morphometric analysis of Hiran river catchment, Jabalpur, Madhya Pradesh using geospatial technique, was attempted by Tignath et al. (2014). Sediment Yield Index and morphometric analysis based prioritization was carried out in Midnapur district of West Bengal by Nooka Ratnam et al. (2005) using remote sensing and Geographical information system. Morphometric analysis and prioritization of sub watersheds in Bino watershed, Uttrakhand has been carried out by Kandapal et al. (2018) using potential of RS and GIS approach. In the present study, efforts were made to prioritize the sub-watersheds of Umar Nala watershed of Narsinghpur district, Madhya Pradesh for soil conservation.

\section{MATERIAL AND METHODS}

Umar Nala watershed lies between 22 39'59.91" \& $22^{\circ} 43^{\prime} 33.93^{\prime \prime} \mathrm{N}$ latitude and $78^{\circ} 45^{\prime} 0.30^{\prime \prime}$ \& $78^{\circ} 48^{\prime} 59.38^{\prime \prime}$ E Longitude, elevation ranges between 374 and $935 \mathrm{~m}$ above mean sea level and covers 2974 ha area (Fig. 1). The watershed falls within the boundary of Narshinghpur, district of Madhya Pradesh. The study area comes under the Central Narmada valley. Average annual rainfall is 1192 $\mathrm{mm}$, temperature varies from $8.2^{\circ} \mathrm{C}$ to $42.5^{\circ} \mathrm{C}$ of the study area. Soil is clay to loamy in texture.

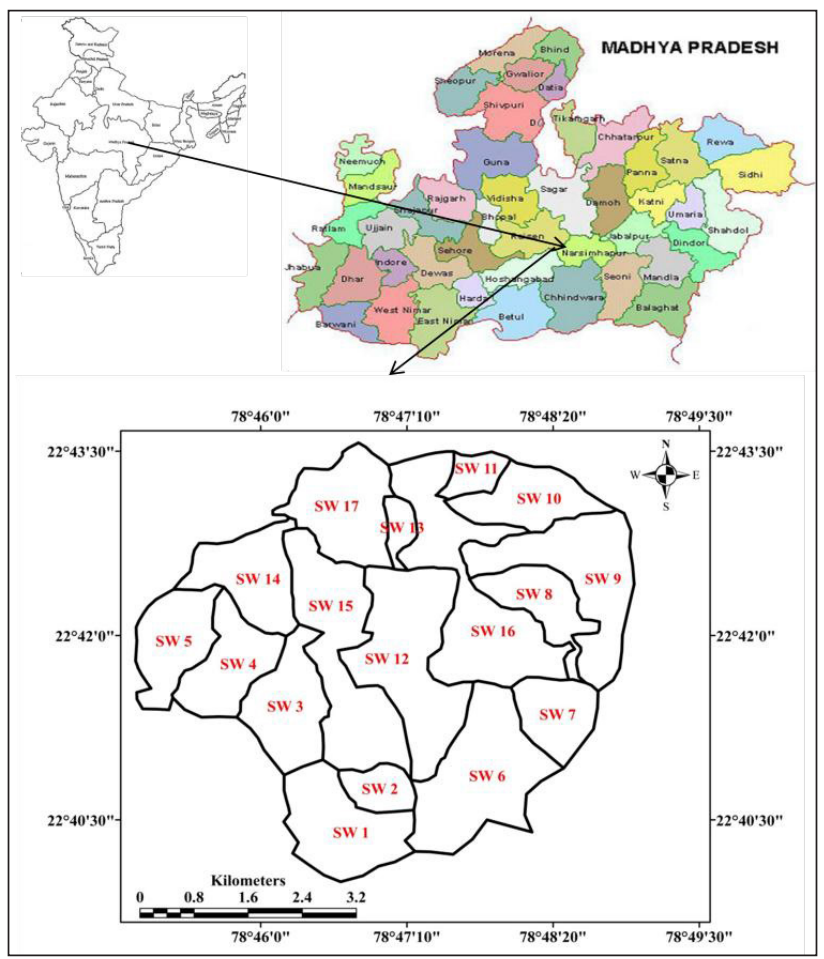

Fig. 1: Location map of study are
To prepare the base map of study area Survey of India toposheet $55 \mathrm{~J} / 14$ on 1:50000 scale was scanned in .jpg format and used for further processing. Toposheet was first imported and georefrenced in ERDAS Imagine then further GIS operations were made in Arc GIS. Digitization of watershed boundary \& its perimeter, sub watersheds boundary \& its perimeter, stream network (Fig. 2) and contours (Fig. 3) were done using Arc GIS.

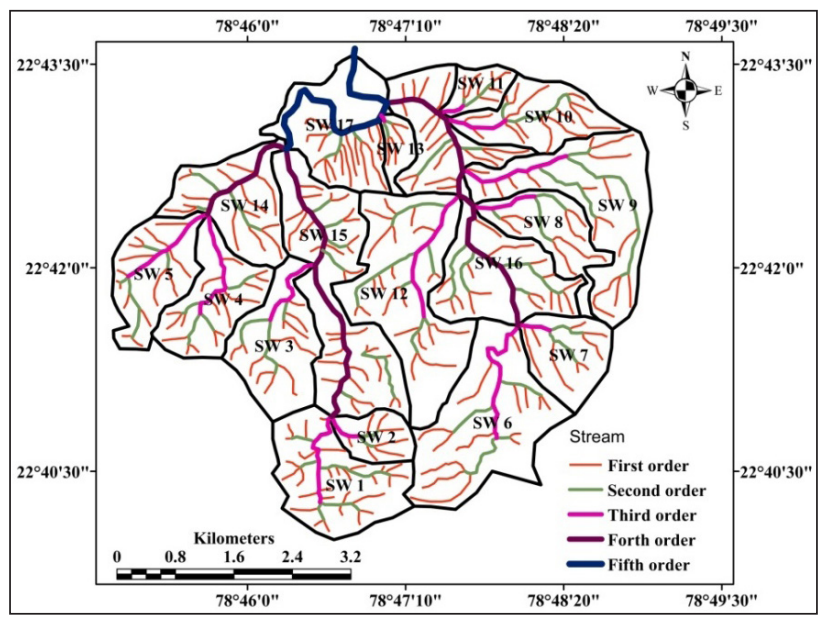

Fig 2 Stream network of Umar nala Watershed

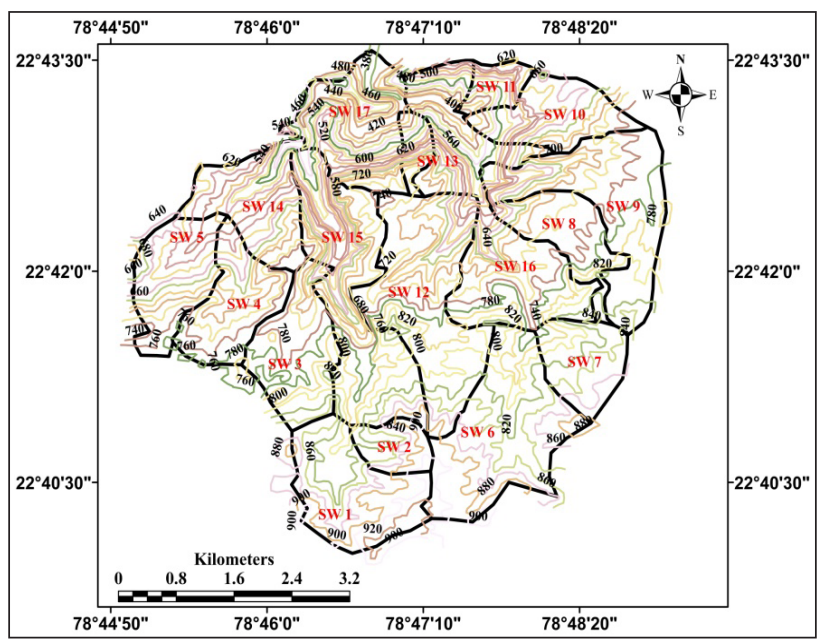

Fig. 3: Contour map of watershed

The digitized boundary, streams and contours were further sub divided for the sub watersheds. These initial parameters were used to determine stream frequency $\left(S_{f}\right)$, drainage density $\left(D_{d}\right)$, texture ratio $(T)$, elongation ratio $\left(R_{e}\right)$, circulatory ratio $\left(R_{c}\right)$, form factor $\left(R_{f}\right)$ and bifurcation ratio $\left(R_{b}\right)$ using standard formulae (Table 1$)$.

On the basis of compound (average) rank values prioritization rating of all sub watershed of Umar Nala watershed was determined. The sub watershed 
Table 1: Formula for computation of morphometric parameters

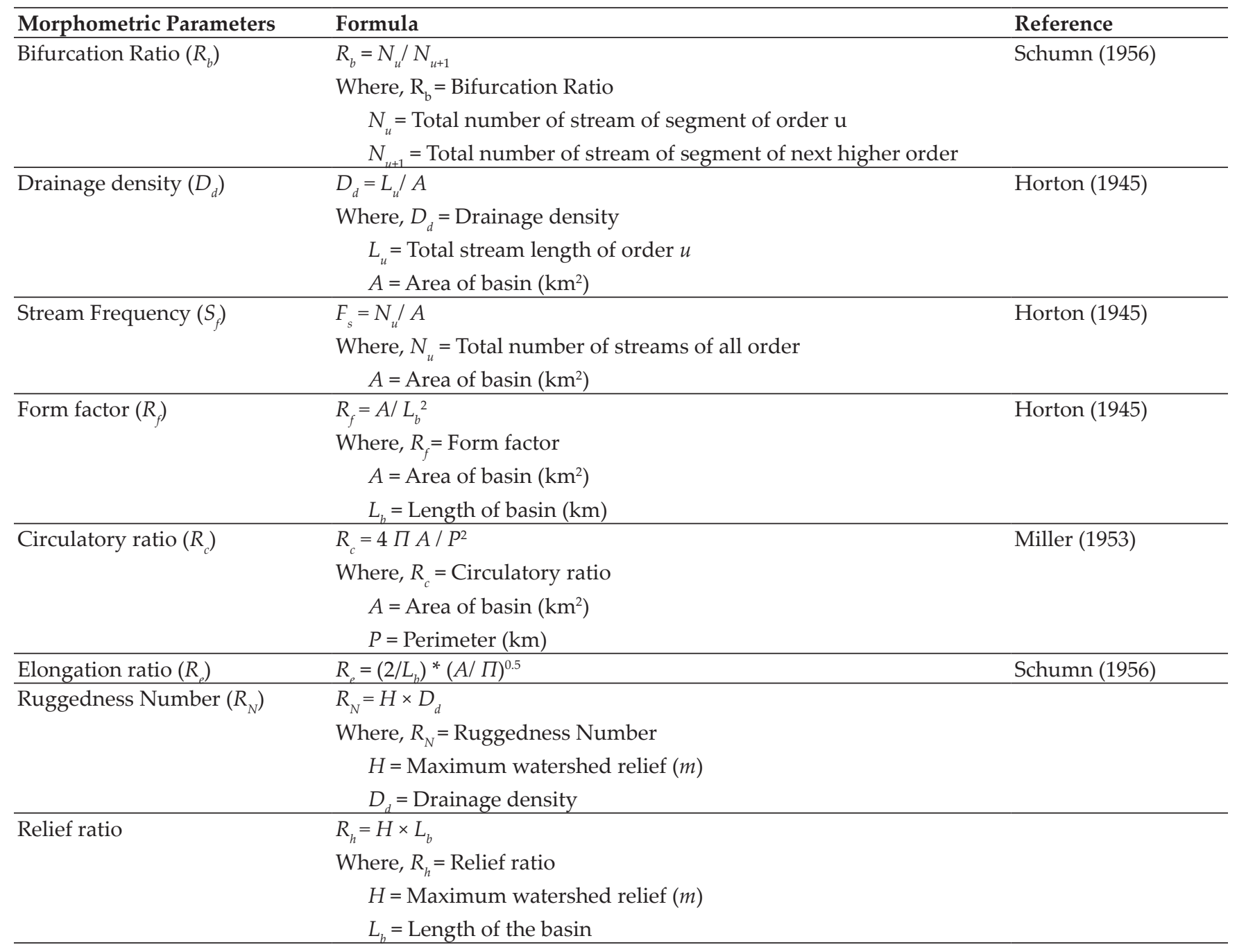

with lowest compound rank value was given the highest priority.

\section{RESULTS AND DISCUSSION}

Stream ordering was given using Straheler (1964) ordering system. Umar Nala watershed is $5^{\text {th }}$ order watershed. The sub-watershed 1 to 13 of third order, 14,15 and 16 forth order and $17^{\text {th }}$ is of fifth order. The stream network is presented in Fig. 2.

The basic morphometric parameters i.e. number of streams; length of streams, max length of watersheds and its area \& perimeter is determined using potential of GIS (Table 2). Morphometric parameters estimated using formulae are presented in Table 3.

Values of bifurcation ratio in sub watersheds ranges between 1.33 for sub watershed 13 and 5.40 for sub watershed 1 . So, lower value of $R_{b}$ of sub watershed
1 shows structurally less disturbed watershed (Sharma et al. 2010). Low value of drainage density i.e. 3.65 (Sub watershed 6) shows the watershed's highly permeable characteristics. However, high value of $D_{d}$ of sub watershed $13\left(D_{d}=17.03\right)$ shows its impermeableness of sub watershed (Gajbhiye et al. 2015). Stream frequency varies between 6.62 of sub watershed 6 and 32.56 of sub watershed 11 and has good agreement with drainage density. Texture ratio values of sub watersheds ranges between 1.43 for sub watershed 8 and 5.83 for sub watershed 1 .

Form factor values of sub watersheds ranges between 0.17 (sub watershed 9) and 0.68 (sub watershed 7). Lower values of $R_{f}$ suggests elongavity of watershed and lower peaks of flow for longer duration. Circulatory ratio values varies between 0.21 (sub watershed 16) and 0.82 (sub watershed 2). Elongation ratio values ranges between 0.47 (sub watershed 9) and 0.93 (sub watershed 7). 
Table 2: Morphometric parameters of sub-watersheds determined in GIS environment

\begin{tabular}{|c|c|c|c|c|c|c|c|c|}
\hline \multirow{2}{*}{$\begin{array}{l}\text { Sub-watershed } \\
\text { No. }\end{array}$} & \multirow{2}{*}{$\begin{array}{l}\text { Perimeter } \\
(\mathrm{km})\end{array}$} & \multirow{2}{*}{$\begin{array}{l}\text { Area } \\
\left(\mathrm{km}^{2}\right)\end{array}$} & \multicolumn{2}{|c|}{ Elevation (m) } & \multirow{2}{*}{$\begin{array}{l}\text { Total } \\
\text { Relief (m) }\end{array}$} & \multirow{2}{*}{$\begin{array}{l}\text { No. of } \\
\text { Streams }\end{array}$} & \multirow{2}{*}{$\begin{array}{l}\text { Max length of } \\
\text { watershed }(\mathrm{km})\end{array}$} & \multirow{2}{*}{$\begin{array}{l}\text { Total Stream } \\
\text { Length }(\mathrm{km})\end{array}$} \\
\hline & & & Max. & Min. & & & & \\
\hline 1 & 6.0 & 2.00 & 919 & 779 & 140 & 35 & 1.82 & 9.75 \\
\hline 2 & 3.0 & 0.59 & 898 & 782 & 116 & 10 & 1.18 & 3.21 \\
\hline 3 & 6.0 & 1.65 & 837 & 604 & 233 & 15 & 2.12 & 6.72 \\
\hline 4 & 6.0 & 1.45 & 782 & 535 & 247 & 21 & 1.95 & 7.45 \\
\hline 5 & 6.0 & 1.43 & 766 & 535 & 231 & 20 & 2.1 & 7.23 \\
\hline 6 & 8.0 & 2.87 & 935 & 750 & 185 & 19 & 2.64 & 10.47 \\
\hline 7 & 4.0 & 1.10 & 886 & 755 & 131 & 11 & 1.27 & 4.66 \\
\hline 8 & 7.0 & 1.15 & 844 & 578 & 266 & 10 & 1.9 & 5.27 \\
\hline 9 & 10.0 & 2.57 & 844 & 448 & 396 & 20 & 3.87 & 11.2 \\
\hline 10 & 6.0 & 1.31 & 748 & 398 & 350 & 16 & 2.31 & 7.67 \\
\hline 11 & 3.0 & 0.43 & 622 & 398 & 224 & 14 & 1.1 & 6.89 \\
\hline 12 & 10.0 & 3.08 & 882 & 520 & 362 & 28 & 3.33 & 11.72 \\
\hline 13 & 3.0 & 0.32 & 771 & 398 & 373 & 8 & 1.06 & 5.45 \\
\hline 14 & 6.0 & 1.59 & 752 & 459 & 293 & 18 & 1.96 & 8.17 \\
\hline 15 & 11.0 & 2.97 & 901 & 479 & 422 & 39 & 3.88 & 14.25 \\
\hline 16 & 14.0 & 3.35 & 841 & 397 & 444 & 40 & 3.36 & 18.72 \\
\hline 17 & 6.0 & 1.88 & 753 & 374 & 379 & 19 & 2.12 & 10.71 \\
\hline
\end{tabular}

Table 3: Computed morphometric parameters of sub-watersheds

\begin{tabular}{lllllllll}
\hline Sub watershed No. & $\boldsymbol{R}_{b}$ & $S_{f}$ & $\boldsymbol{D}_{\boldsymbol{d}}$ & $\boldsymbol{T}$ & $\boldsymbol{R}_{f}$ & $\boldsymbol{R}_{e}$ & $\boldsymbol{R}_{c}$ & $\boldsymbol{R}_{h}$ \\
\hline 1 & 5.40 & 17.50 & 4.88 & 5.83 & 0.60 & 0.88 & 0.70 & 0.08 \\
2 & 2.75 & 16.95 & 5.44 & 3.33 & 0.42 & 0.73 & 0.82 & 0.10 \\
3 & 3.33 & 9.09 & 4.07 & 2.50 & 0.37 & 0.68 & 0.58 & 0.11 \\
4 & 4.00 & 14.48 & 5.14 & 3.50 & 0.38 & 0.70 & 0.51 & 0.13 \\
5 & 3.88 & 13.99 & 5.06 & 3.33 & 0.32 & 0.64 & 0.50 & 0.11 \\
6 & 3.75 & 6.62 & 3.65 & 2.38 & 0.41 & 0.72 & 0.56 & 0.07 \\
7 & 3.00 & 10.00 & 4.24 & 2.75 & 0.68 & 0.93 & 0.86 & 0.10 \\
8 & 2.50 & 8.70 & 4.58 & 1.43 & 0.32 & 0.64 & 0.29 & 0.14 \\
9 & 4.17 & 7.78 & 4.36 & 2.00 & 0.17 & 0.47 & 0.32 & 0.10 \\
10 & 4.25 & 12.21 & 5.85 & 2.67 & 0.25 & 0.56 & 0.46 & 0.15 \\
11 & 1.92 & 32.56 & 16.02 & 4.67 & 0.36 & 0.67 & 0.60 & 0.20 \\
12 & 4.75 & 9.09 & 3.81 & 2.80 & 0.28 & 0.59 & 0.39 & 0.11 \\
13 & 1.33 & 25.00 & 17.03 & 2.67 & 0.28 & 0.60 & 0.45 & 0.35 \\
14 & 2.33 & 11.32 & 5.14 & 3.00 & 0.41 & 0.73 & 0.55 & 0.15 \\
15 & 2.21 & 13.13 & 4.80 & 3.55 & 0.20 & 0.50 & 0.31 & 0.11 \\
16 & 2.75 & 11.94 & 5.59 & 2.86 & 0.30 & 0.61 & 0.21 & 0.13 \\
17 & 2.50 & 10.11 & 5.70 & 3.17 & 0.42 & 0.73 & 0.66 & 0.18 \\
\hline
\end{tabular}

Relief ratio shows the steepness of watershed. In the present study $R_{h}$ values of the sub-watersheds vary from 0.07 to 0.35 (Table 2) suggesting gentle slope in the sub watershed 6 and steep slope in sub watershed 13 (Meshram and Sharma, 2018).

Biswas et al. (1999) in their study stated that the parameters i.e. drainage density, stream frequency bifurcation ratio, texture ratio, elongation ratio circulatory ratio, form factor and relief ratio parameters are the erosion risk evaluation parameters which can be used for prioritization of sub-watersheds. Morphometric parameters viz. drainage density, stream frequency, bifurcation ratio, texture ratio and relief ratio parameters have a direct relationship with erodibility, higher the value; more is the erodibility (Sharma et al. 2012). Therefore, for prioritization of sub-watersheds, the highest value of linear and relief parameters was taken as rank 1 , and second highest value was taken as rank 2 and so on, and the least value was taken last in rank. Shape 
Table 4: Final priority of sub-watersheds and their rank

\begin{tabular}{lllllllllll}
\hline Sub watershed no & $\boldsymbol{R}_{b}$ & $S_{f}$ & $\boldsymbol{D}_{\boldsymbol{d}}$ & $\boldsymbol{T}$ & $\boldsymbol{R}_{f}$ & $\boldsymbol{R}_{e}$ & $\boldsymbol{R}_{c}$ & $\boldsymbol{R}_{h}$ & $C_{p}$ & Final Priority \\
\hline 1 & 1 & 3 & 10 & 1 & 16 & 16 & 15 & 16 & 9.75 & 11 \\
2 & 10 & 4 & 6 & 5 & 15 & 3 & 16 & 15 & 9.25 & 10 \\
3 & 8 & 13 & 15 & 14 & 10 & 10 & 12 & 10 & 11.50 & 15 \\
4 & 5 & 5 & 8 & 4 & 11 & 11 & 9 & 10 & 7.88 & 7 \\
5 & 6 & 6 & 9 & 5 & 8 & 8 & 8 & 9 & 7.38 & 6 \\
6 & 7 & 17 & 17 & 15 & 12 & 12 & 11 & 17 & 13.50 & 16 \\
7 & 9 & 12 & 14 & 11 & 17 & 17 & 17 & 13 & 13.75 & 17 \\
8 & 12 & 15 & 12 & 17 & 7 & 7 & 2 & 6 & 9.75 & 11 \\
9 & 4 & 16 & 13 & 16 & 1 & 1 & 4 & 14 & 8.63 & 9 \\
10 & 3 & 8 & 3 & 12 & 3 & 3 & 7 & 4 & 5.38 & 1 \\
11 & 16 & 1 & 2 & 2 & 9 & 9 & 13 & 2 & 6.75 & 4 \\
13 & 2 & 14 & 16 & 10 & 4 & 4 & 5 & 12 & 8.38 & 8 \\
15 & 17 & 2 & 1 & 12 & 5 & 5 & 6 & 1 & 6.13 & 2 \\
16 & 14 & 10 & 7 & 8 & 13 & 13 & 10 & 5 & 10.00 & 14 \\
\hline
\end{tabular}

parameters such as elongation ratio, circulatory ratio and form factor have an inverse relationship with erodibility lower the value, more is the erodibility (Sharma et al. 2012). Thus the lowest value of shape parameters was rated as rank 1, next lower value was rated as rank 2 and so on and the highest value was rated last in rank. So, the ranking of the subwatersheds has been determined by assigning the highest/rank based on highest value in case of linear and relief parameters and lowest value in case of shape parameters (Table 4).

After assigning the ranks based on different parameters, the ranking values for all the linear, relief and shape parameters are added up for each of the sub-watersheds to arrive at compound value $\left(C_{p}\right)$. Based on average value of these parameters, the sub-watershed having the least rating value was assigned highest priority, next higher value was assigned second priority and so on. The sub-watershed which got the highest $C_{p}$ value was assigned last priority. Hence, on the basis of morphometric analysis sub-watershed 10 falls in the top priority and sub-watershed 7 on the last priority to start the soil conservation work in Umar Nala watershed.

\section{CONCLUSION}

The present study demonstrate the utility of remote sensing and GIS technique in prioritizing sub- watersheds based on morphometric analysis. This study has found that sub-watershed 10 falls on the top priority; hence, this prioritization may be taken for soil conservation measures by planners and decision makers for locale-specific planning and development.

\section{REFERENCES}

Biswas, S., Sudhakar, S. and. Desai, V.R. 1999. Prioritization of Subwatershed based on Morphometric Analysis of Drainage Basins - A Remote Sensing and GIS Approach. J. Indian Soc. Remote Sens., 27(3): 155-166.

Gajbhiye, S., Sharma, S.K. and Tignath, S. 2015. Development of geomorphological erosion index for Shakker watershed. Journal of Geological Society of India, 86(3).

Horton, R.E. 1932. Drainage basin characteristics. Trans. Am. Union, 13: 350-361.

Horton, R.E. 1945. Erosional development of streams and their drainage basin hydrological approach to quantitative morphology. Geol. Soc. Am. Bull., 56: 275-370.

Kandapal, H., Kumar, A. and Malik, A. 2018. Morphometric analysis and prioritization of sub-watersheds in Bino watershed, Uttarakhand: A remote sensing and GIS perspective. Indian Journal of Ecology, 45(3): 475-478.

Meshram, S.G. and Sharma, S.K. 2018. Application of principal component analysis for grouping of morphometric parameters and prioritization of water shed. Hydrological Modeling, Select proceedings ICWEES-2016 (Springer). Editors: Singh V P, Yadav Shalini and Yadav Ramnarayan, pp. 447-458. 
Miller, V.C. 1953. A quantitative geomorphic study of drainage basin characteristics in the Clinch mountain area Virginia and Tennesses. Deptt. of Navy, Office of Naval Res., Technical Report 3, Project NR 389-042, Washington DC.

Noorkaratnam, K., Shrivastava, Y.S., Venkateshwara Rao, V., Amminedu, E. and Murthy, K.S.R. 2005. Check dam positioning by prioritization of micro watershed using SYI model and morphometric analysis - remote sensing and GIS perspective. J. Indian Soc. Remote Sens., 33(1): 25-38.

Patle, D. and Awasthi, M.K. 2019a. Past Two Decadal Groundwater Level Study in Tikamgarh District of Bundelkhand. Journal of the Geological Society of India, 94(4): 416-418.

Patle, D. and Awasthi, M.K. 2019b. Groundwater Potential Zoning in Tikamgarh District of Bundelkhand Using Remote Sensing and GIS. International Journal of Agriculture, Environment and Biotechnology, 12(4): 311-318.

Patil, R.J., Sharma, S.K., Tignath, S. and Sharma, A.P.M. 2016. Use of remote sensing, GIS and $\mathrm{C}^{++}$for soil erosion assessment in Shakker river basin, India. Hydrological Sciences Journal, 62(2), 217-231.

Rao, J.H. 2019. Water Footprint Assessment of Agriculture in Banjar River Watershed. Unpublished M.Tech Thesis, Departemt of Soil \& Water Engineering, College of Agricultural Engineering, JNKVV, Jabalpur.

Rao, J.H., Hardaha, M.K. and Vora, H.M. 2019. The Water Footprint Assessment of Agriculture in Banjar River Watershed. Current World Environment, 14(3): 476 - 488.

Schumm, S.A. 1956. Evaluation of drainage system and slopes in bed lands at Perth Ambry, New Jersy. Geolo. Soc. Am. Bull., 67: 597-646.

Sharma, S.K., Gajbhiye, S., Patil, R.J. and Tignath, S. 2016. Hypsometric analysis using Geographical Information System of Gour river watershed, Jabalpur, Madhya Pradesh, India. Current World Environment, 11(1): 56-64.
Sharma, S.K., Rajput, G.S., Tignath, S. and Pandey, R.P. 2010. Morphometric Analysis of and prioritization of Watershed using GIS. Jour Indian Water Resources Society, 30(2): 33-39.

Sharma, S.K. and Seth, N.K. 2010. Use of Geographical Information System (GIS) in assessing the erosion status of watersheds. Sci-fronts A Journal of Multiple Science, 4(4): 77-82.

Sharma, S.K., Seth, N.K., Tignath, S. and Shukla, J.P. 2011. Morphological study of watershed using Remote Sensing and GIS approach. J.N.K.V.V. Research Journal, 45(2): 175180.

Sharma, S.K., Tignath, S. and Mishra, S.K. 2008. Morphometric analysis of Drainage basin using GIS approach. J.N.K.V.V. Research Journal, 42(1): 91-95.

Sharma, S.K., Tignath, S., Gajbhiye, S. and Patil, R.J. 2013. Use of Geograpical Information System in Hypsometric analysis of Kanhiya Nala Watershed. International Journal of Remote Sensing and Geosciences, 2(3): 30-35.

Sharma, S.K., Pathak, R. and Suraiya, S. 2012. Prioritization of sub-watersheds based on morphometric analysis using remote sensing and GIS technique. J.N.K.V.V. Research Journal, 46(3): 407-413.

Sharma, S.K., Tignath, S. and Mishra, S.K. 2008. Morphometric analysis of Drainage basin using GIS approach. J.N.K.V.V. Research Journal, 42(1): 91-95.

Smith, K.G. 1950. Standards for grading textures of erosional topography. Am Jour. Sci., 248: 655-668.

Strahler, A.N. 1964. Quantitative geomorphology of drainage basins and channel networks, Handbook of Applied Hydrology: Ed. By Ven Te Chow, McGraw Hill Book Company, New York. 55-67.

Tignath, S., Kapoor, M., Jha, M. and Sharma, S.K. 2014. Morphometric analysis of part of the Hiran river, district Jabalpur, M.P., India using remote sensing and GIS. International Journal of Environmental Sciences, 5(1): 181-196. 